\title{
Evaluation of sodium isobutyl xanthate as a collector in the froth flotation of a carbonatitic copper ore
}

\author{
N. T. N. Langa $\cdot$ A. A. Adeleke $\cdot$ P. Mendonidis $\cdot$ \\ C. K. Thubakgale
}

Received: 22 February 2014 / Accepted: 14 October 2014/Published online: 25 October 2014

(C) The Author(s) 2014. This article is published with open access at Springerlink.com

\begin{abstract}
The dosage of a collector is an important factor that determines the efficiency of a froth flotation process. The representative sample of the carbonatitic Palabora copper ore ground $45 \%$ passing $75 \mu \mathrm{m}$ was froth-floated with sodium isobutyl xanthate (SIBX) collector at 60,70 , 80,90 and $100 \mathrm{~g} / \mathrm{t}$ dosages. The concentrates and tails were dried and analysed. The results obtained showed that the highest recovery of $85.18 \%$ with a grade of $12.61 \%$ was obtained at the $80 \mathrm{~g} / \mathrm{t}$ dosage. It was further observed that the copper grade of the concentrate generally decreased with increasing recovery. The particle size distribution analysis of the tailings showed that the froth flotation was most efficient in the fine particle size range 38-75 $\mu \mathrm{m}$.
\end{abstract}

Keywords Copper ore $\cdot$ Collector - Dosage $\cdot$ Recovery · Grade $\cdot$ Tailings

\section{Introduction}

The Palabora mine carbonatitic complex is the largest producer of copper in South Africa. The mine is also a major source of vermiculite, baddeleyite, nickel sulphate, uranium and phosphates. The carbonatite complex is the only one known in the world that contains sufficient copper as sulphides to qualify as an economic deposit. It is a

N. T. N. Langa $\cdot$ P. Mendonidis · C. K. Thubakgale Department of Metallurgical Engineering, Vaal University of Technology, Vanderbijlpark, South Africa

\section{A. A. Adeleke ( $\square)$}

Department of Materials Science and Engineering, Obafemi

Awolowo University, Ile-Ife, Nigeria

e-mail: adeadeleke@oauife.edu.ng magnetite-copper deposit hosted within a pyroxenite-carbonatite complex with minor constituent of gold $[3,4,6]$.

Flotation is an essential and resourceful technique in the mineral processing industry. The technique is based on the differences in the surface properties of different minerals, which cause them to have affinity either for water or for air bubbles. The flotation method works due to the action of reagents such as collectors, frothers and depressants. Collectors are organic compounds which render selected minerals water-repellent by adsorption of molecules or ions on to the mineral surface, reducing the stability of the hydrated layer separating the mineral surface from the air bubble to such a level that attachment of the particle to the bubble can be made on contact. Collectors make the minerals hydrophobic, thus allowing them to attach to the air bubbles and rise to the surface, frothers create froth on the pulp surface, which is easily recovered and the depressants cause the naturally floating gangue to become hydrophilic and thus remain in the cell as tailings [8].

Standard copper sulphide flotation collector reagents are sulphur-based thiol class collectors, which can be grouped into the main xanthate, dithiophosphate, thionocarbamate and thiocarbamate families [8]. The amount of reagent required for a particular application is influenced by factors like variations in particular size, mass of particle, quantity of mineral, and the character of the host rock. Xanthates are ionising anionic sulfhydryl collectors that are powerful and selective in the flotation of sulphide minerals [8]. They adsorb on to the sulphide mineral surface and form insoluble metal xanthates which are very hydrophobic. The four common xanthate collectors are sodium isobutyl, sodium ethyl, sodium normal propyl and potassium amyl xanthate [7].

In this research, the optimal dosage of SIBX collector for the froth flotation of Palabora ore was determined to 
ensure the efficient froth flotation of the ore with this collector.

\section{Materials and methods}

Materials

Sample collection

About $150 \mathrm{~kg}$ of Palabora copper ore was collected from the Palabora Mining Company. From the bulk sample, about $20 \mathrm{~kg}$ was taken for this study.

\section{Sample preparation}

The ore received from Palabora Mining Company comprised various lumps of rocks to fine material. The bulk sample was crushed in a jaw crusher and various size fractions were obtained ranging from -2 to $+4 \mathrm{~mm}$. The various size fractions were screened using the 2 and $4 \mathrm{~mm}$ sieves. Three size fractions $>4 \mathrm{~mm},<4 \mathrm{~mm}>2 \mathrm{~mm}$ and $<2 \mathrm{~mm}$ were obtained. A representative mixture was then obtained from these fractions by coning and quartering.

\section{The reagents}

The reagents used were SIBX collector and Dow froth frother B supplied by Senmin.

Methods

\section{Froth flotation}

A milling curve for the Palabora copper ore was first derived. The ball mill was turned so that it was facing vertically upward. The required number of steel balls was poured inside the mill and about $1.5 \mathrm{~kg}$ of the sample was delivered into the mill. The mill was closed and the timer was set on the mill panel. The sample was ground for $10 \mathrm{~min}$ and the power was switched off. The grinding balls were removed and the ground ore was then emptied into a bucket. The milled sample was wet screened with a $75 \mu \mathrm{m}$ sieve. The wet screened sample residue was dried and weighed to determine the percentage that passed the $75 \mu \mathrm{m}$ sieve. The procedure described was repeated but at 10, 20, 30, 40, 50 and $60 \mathrm{~min}$ grinding times. The tests were carried out in duplicates. Using the data obtained, the milling curve was constructed.

The Senmin sodium isobutyl xanthate (SIBX) collector was prepared at $6 \%$ strength. About $60 \mathrm{~g}$ SIBX powder was weighed in a $1 \mathrm{~L}$ volumetric flask. Distilled water was added to make up to $1,000 \mathrm{ml}$ and the flask was well shaken to ensure the dissolution of the powder. About
$1.5 \mathrm{~kg}$ of the sample milled $45 \%$ passing $75 \mu \mathrm{m}$ was poured into a $4.5 \mathrm{~L}$ Denver cell to make a slurry density of $1.3 \mathrm{~kg} / \mathrm{L}$. All the milled ore was washed into the bucket. The cell and its contents were weighed and its mass was recorded. The flotation cell was then placed in the base of the Denver flotation machine. The flotation impeller was lowered into the slurry in the flotation cell. A clean concentrate collection pan was placed under the overflow lip of the cell. The flotation machine was switched on and the agitator was set at the speed of 1,000 rpm. The reagentscollector (SIBX) and frother (Dowfroth) were added with conditioning time of $2 \mathrm{~min}$. The air valve was then opened. The froth was scraped towards the overflow every $15 \mathrm{~s}$ in 3, 7 and $10 \mathrm{~min}$ froth scraping time. The slurry level was adjusted and kept constant by adding $500 \mathrm{ml}$ of water to the flotation cell every $5 \mathrm{~min}$. The air valve was then closed and the agitator stopped. The Denver machine was electrically isolated. The three concentrates and the tail residue were taken to the oven for drying at $105^{\circ} \mathrm{C}$. The experiments were done in duplicates.

\section{$X$-ray fluorescence analysis}

The sample for the XRF analysis was first prepared. Two and a half spatula of boric acid and two spatula of the powder sample were mixed in a beaker. The mixture was poured into the mounting press and moulded at pressure above 400 bars. The pellet obtained was labelled. The sample was then subjected to X-ray fluorescence analysis according to standard [1].

\section{Results and discussion}

The screen distribution analysis for the mill feed in aperture ranges $A \quad(<38), \quad B \quad(-63+38), \quad C \quad(-75+63)$, $D(-125+75), \quad E(-150+125), \quad F(-212+150)$, $G(-300+212), H(-425+300 \mu \mathrm{m})$ is presented in Fig. 1. It is observed that the percentage passing $75 \mu \mathrm{m}$ in the feed is very low, that is, $9.33 \%$. The results indicate that further grinding is required to obtain the set flotation target of $40 \%$ passing 75 microns. It has been found that flotation occurs most efficiently in the particle size range 38-106 $\mu \mathrm{m}$. The consideration of the entire size distribution curve is necessary as a mill may produce the required $\%<75 \mu \mathrm{m}$ and still produce a large amount of coarse material [2].

Figure 2 shows the milling curve obtained for the Palabora copper ore. The results obtained showed that the time required to obtain the grind of $45 \%$ passing 75 microns was $20 \mathrm{~min}$. A critical step in grinding is ensuring that the final particles from grinding are fine enough for efficient flotation. Coarser particles must be isolated and returned for further grinding. Since grinding requires 


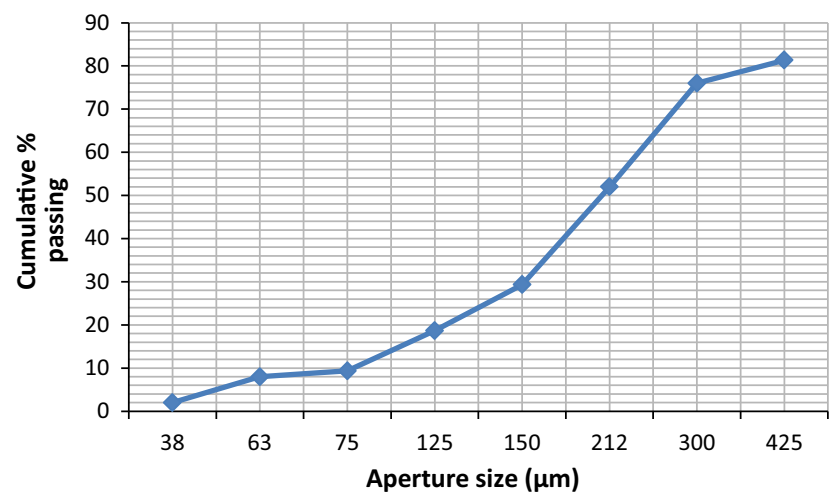

Fig. 1 Particle size distribution (PSD) of the mill feed

considerable of input electrical energy, it is necessary to avoid over grinding [2].

Figure 3 shows copper recoveries obtained for each of the SIBX dosages tested. It was observed that there was an increase in recovery from 60 to $80 \mathrm{~g} / \mathrm{t}$ dosage followed by a decrease at $90 \mathrm{~g} / \mathrm{t}$. The initial trend of increasing recovery at increasing SIBX dosage can be attributed to more sulphide being floated by the increased amount of collector added; with the highest recovery obtained at the SIBX dosage of $80 \mathrm{~g} / \mathrm{t}$. The results obtained thus suggest the $80 \mathrm{~g} / \mathrm{t}$ dosage as the most efficient dosage for SIBX in floating the Palabora copper ore ground $45 \%$ passing $75 \mu \mathrm{m}$.

Figure 4 shows how recovery increases with time during the batch flotation tests. It was observed that the highest recoveries in 5 and $10 \mathrm{~min}$ froth scraping were obtained at $70 \mathrm{~g} / \mathrm{t} \mathrm{SIBX}$ dosage and the highest at $20 \mathrm{~min}$ at $80 \mathrm{~g} / \mathrm{t}$ dosage. The results obtained suggest the 70 and $80 \mathrm{~g} / \mathrm{t}$ dosages as the one that promoted the most efficient flotation. Figure 5 shows the recovery-grade curve which follows the generic inverse proportion trend. The decrease in copper grade with increase in collector dosage agrees with the observation of Mpongo and Siame [5] on the flotation of copper sulphide from the Nchanga sulphide-oxide copper ore. The results obtained show that increasing the collector dosage does not cause a corresponding increase in the copper grade of the concentrate obtained. It was observed that an increase in the sodium isopropyl xanthate collector up to $30 \mathrm{~g} / \mathrm{t}$ leads to an increase in copper grade and then a decrease in grade at 50 and almost no increase at $80 \mathrm{~g} / \mathrm{t}$. As expected, the recovery of copper to the concentrate was observed to be inversely proportional to the grade value. This behaviour was said to be probably due to the fact that an excessive concentration of the collector has an adverse effect on the recovery of the valuable minerals due to the development of multi-layers on the mineral particles, which reduce the proportion of hydrocarbon

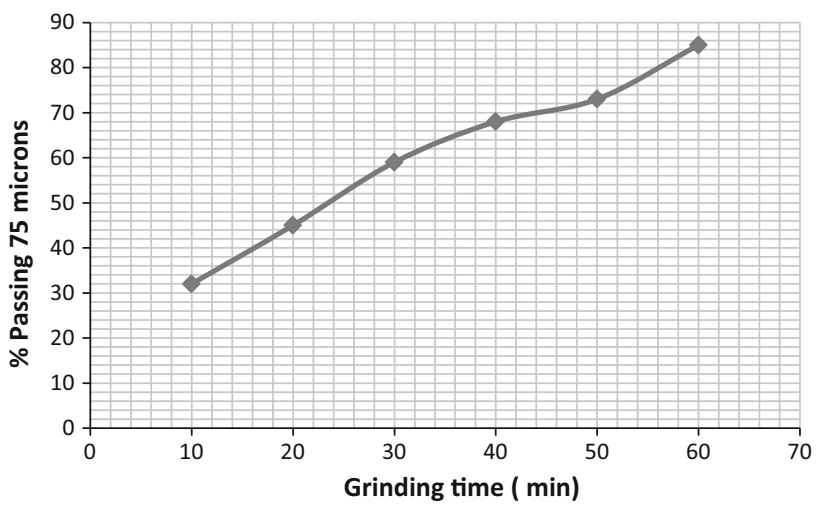

Fig. 2 Milling curve for Palabora copper ore

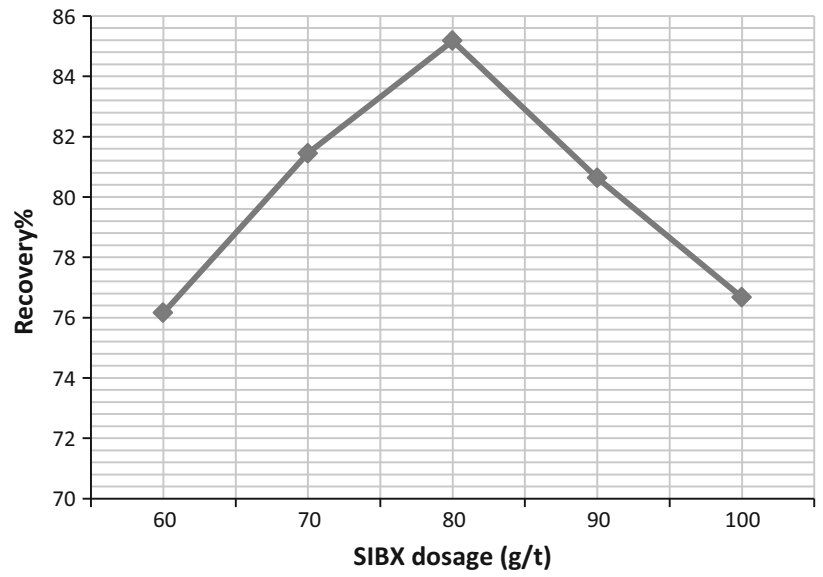

Fig. 3 Effects of SIBX dosage on copper recovery (R)

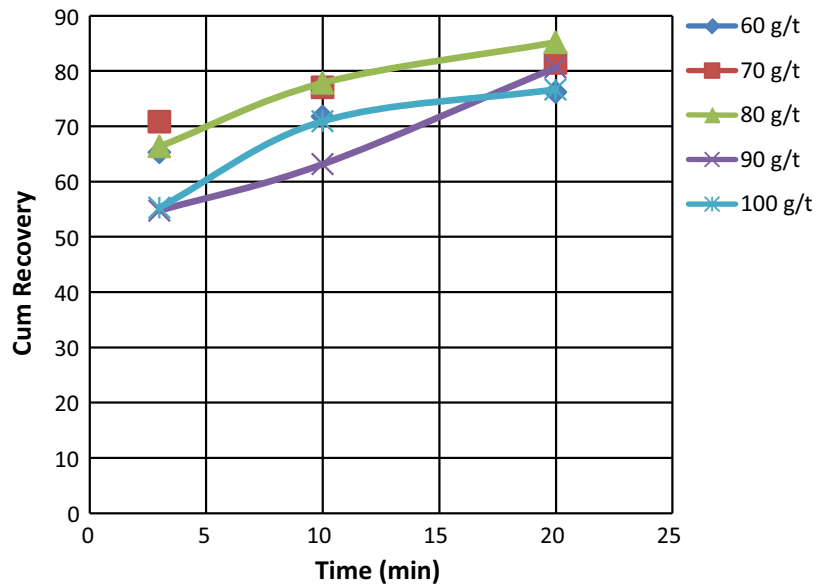

Fig. 4 Recovery: time curve for Palabora copper ore

radicals oriented into the bulk solution. The hydrophobicity of the mineral particles is thus reduced and hence, their floatability [8].

Figure 6 shows the particle size distribution of the tailings which shows that a significant amount of the 


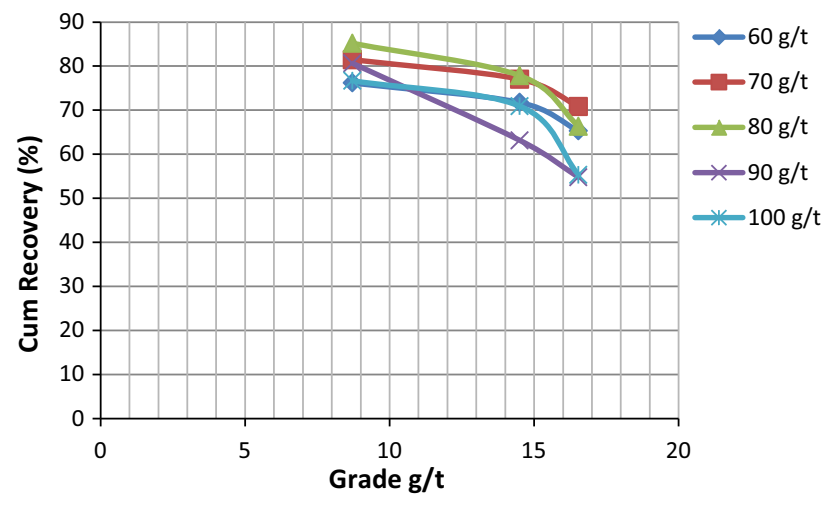

Fig. 5 Recovery: grade curve for Palabora copper ore

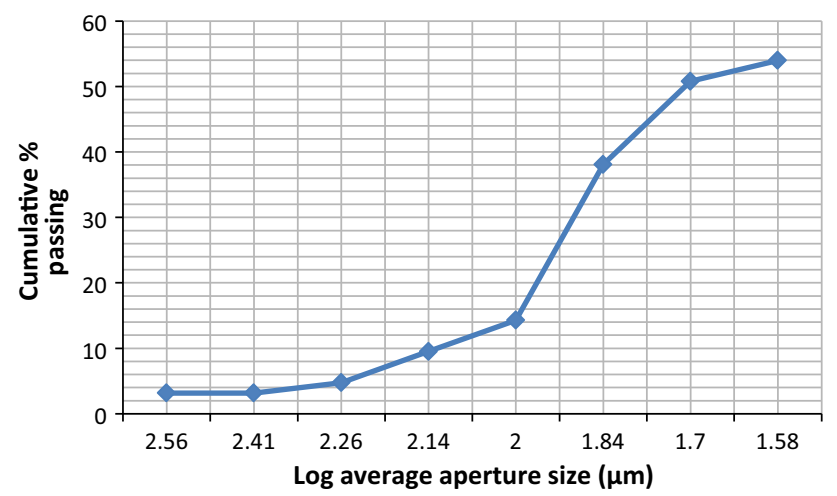

Fig. 6 Particle size distribution of the Palabora copper ore tailings

various size fractions were floated during flotation. The percentage passing 425 microns has decreased from $81.33 \%$ in the PSD of the mill feed to $53.97 \%$ in the tailings indicating that the ball mill sufficiently liberated the copper minerals to produce the required sizes for froth flotation. Flotation occurs most efficiently in the range $38-106 \mu \mathrm{m}$ this is emphasised by the reduced percentage passing these size fractions in the particle size distribution of the tailings indicating efficient milling and flotation.

\section{Conclusions}

The Palabora copper ore ground $45 \%$ passing $75 \mu \mathrm{m}$ was successfully froth-floated with SIBX collector at varying dosages. The results obtained showed that the highest recovery of copper into the concentrate was obtained at $80 \mathrm{~g} / \mathrm{t}$ dosage. It was further observed that the concentrate grade decreased with increasing recovery in accordance with the established generic trend between grade and recovery. The particle distribution analysis of the tailings confirmed that the froth flotation occurred most efficiently in the fine particle size range $38-106 \mu \mathrm{m}$.

Open Access This article is distributed under the terms of the Creative Commons Attribution License which permits any use, distribution, and reproduction in any medium, provided the original author(s) and the source are credited.

\section{References}

1. ASTM International E60-11 (2013) Analytical chemistry standards. Standard practice for analysis of metals, ores and related materials by spectrophotometry. http://www.astm.org/Standards/ analytical-chemistry-standards.html. Accessed 31 Jan 2014

2. Davenport WG, King M, Schlesinger M, Biswas AK (2000) Extractive metallurgy of copper, 4th edn. Elsevier Science Ltd, Oxford

3. Groves DI, Vielreicher NM (2001) The Phalabowra (Palabora) carbonatite-hosted magnetite-copper sulphide deposit, South Africa: an end-member of the iron-oxide copper-gold-rare earth element deposit group? Miner Depos 36:189-194. Springer. http:// link.springer.com/article/10.1007/s001260050298\#page-2. Accessed 16 July 2014

4. Heinrich EWM (1970) The Palabora carbonatitic complex; a unique copper deposit. Canad Mineral 10:585-598. http://rruff. info/doclib/cm/vol10/CM10_585.pdf. Accessed 16 July 2014

5. Mpongo MK, Siame E (2006) Effect of collector, frother and depressant addition on the copper recovery and concentrate grade of the Nchanga underground scavenger circuit of Konkola copper mine-Zambia. Afr J Sci Technol (AJST) Sci Eng Ser 7(1):8-11

6. Sharaky AM (2011) Mineral resources and exploration in Africa. http://african.cu.edu.eg/Dr_Abbas/Papers/Minerals_2011.pdf. Accessed 16 July 2014

7. Wiese J, Harris P, Bradshaw D (2005) Investigation of the role and interactions of a dithiophosphate collector in the flotation of sulphides from the Merensky reef. Miner Eng 18:791-800

8. Wills BA (2006) Mineral processing technology, 7th edn. Pergamon Press, Oxford 